\title{
ENTREVISTA POR UMA ANTROPOLOGIA DO CENTRO
}

\author{
Bruno Latour
}

Esta entrevista foi realizada em Paris, em fevereiro de 2004, no gabinete de Bruno Latour na École Nationale Supérieure des Mines, por Renato Sztutman e Stelio Marras. A École des Mines oferece, tradicionalmente, cursos em geofísica, engenharia de materiais e energia, robótica, matemática, economia industrial, mecânica, reatores. Ali, Latour ensina sociologia, no quadro da formação oferecida pelo "Centre de sociologie de l'innovation", mas parece preferir não ser tomado por um sociólogo. Sua formação é em filosofia, embora ele não se diga filósofo.

Epistemólogo seria, ainda talvez, uma designação mais justa. Se bem que ele não recusaria de todo o rótulo de historiador das ciências. Ele próprio se define como um "sujeito híbrido". Visto como um antropólogo, Latour seria um antropólogo da modernidade - mais especificamente, um antropólogo da ciência ou da natureza. Como ciência humana das coisas, esta antropologia da natureza não adere, contudo, seja ao realismo das ciências naturais, seja ao construtivismo das humanidades. Latour situa sua perspectiva nem de um lado, nem de outro, mas no meio - no centro, precisamente onde ocorre seu objeto de estudo por excelência, os híbridos ou matters of concern, isto é, as coisas ao mesmo tempo naturais e domesticadas, os quase-sujeitos e quase-objetos dotados simultaneamente de objetividade e paixão. E é também no centro do Ocidente e de seus coletivos modernos que se processa a produção e proliferação desses híbridos, em paralelo à prática, tipicamente moderna, de sua purificação. É por isso que os laboratórios de alta tecnologia, por exemplo, são lugares privilegiados de investigação etnográfica para uma antropologia das ciências, coração de uma antropologia da modernidade. Metodologicamente, trata-se de seguir as coisas através das redes em que elas se transportam, descrevê-las em seus enredos - é preciso estudá-las não a partir dos pólos da natureza ou da sociedade, com suas respectivas visadas críticas sobre o pólo oposto, e sim simetricamente, entre um e outro.

Por meio de uma dezena de livros e de centenas de artigos e ensaios, as idéias de Latour vão se estendendo, também em rede, pelos continentes. Seu livro-manifesto Jamais fomos modernos - ensaio de antropologia simétrica (publicado na França em 1991, no Brasil em 1994), foi traduzido em 18 línguas. Ao desmontar ali a ilusão moderna de que é possível isolar o domínio da natureza (o inato) do domínio da política (a ação humana), Latour reconectou a modernidade a todas as demais naturezas-culturas do globo, delineando propostas para uma possível convivência intraplanetária. Quase como um profetismo às avessas, o novo mundo para onde Latour aponta é idêntico ao mundo tal qual ele sempre foi, mas que nunca os modernos, antes, pudemos notar. 
Sociologia da crítica, antropologia da ciência, science studies... Qual o meIhor modo de se referir ao seu campo de pesquisa? Seria essa aparente indefinição um sintoma da urgência de uma redefinição dos instrumentos capazes de iluminar os mecanismos da modernidade?

Em termos de "disciplina", o que eu faço não existe. Meu trabalho se situa ao lado da história das ciências, da nova história das ciências - a área que mais atrai gente hoje no mundo universitário - , daquilo que costumamos chamar de science studies, expressão que não tem correspondente direto em francês, e que é a tradução em inglês da palavra grega "epistemologia". Sempre colaborei com os antropólogos, e de vez em quando gosto de me definir como um antropólogo das ciências. Esse rótulo agora é menos útil, graças ao trabalho de Philippe Descola, que vem desenvolvendo a escola da "antropologia da natureza" (este é o nome de seu curso no Collège de France), e eu fico muito contente em fazer parte dela. Mas ao mesmo tempo, aqui [na École des $M$ ines], eu ensino sociologia. $M$ inha formação é unicamente em filosofia, meus diplomas são em filosofia. Assim, os rótulos não são fáceis de estabelecer. Por outro lado, se definirmos pelo objeto, o único objeto que estudo é o que chamei, de início, de “objetos híbridos", e que chamo agora de matters of concern, em oposição aos matters of fact. É o que interessa também ao pessoal dos science studies, os antropólogos da ciência, os historiadores da ciência, que convergem para este objeto que tem características novas e que podemos definir como - segundo o antigo sentido desses termos things em inglês, choses em francês: coisas, ou seja, seres que têm necessi- dade de uma representação, no duplo sentido da palavra, como tentei precisar no livro Politiques de la Nature (2000). Assim, para responder à questão, em termos de rótulo, não disponho de uma definição precisa para oferecer. No entanto, em termos de objeto, penso que meu objeto é o estudo dos matters of concern, a invenção de um certo empirismo - um segundo empirismo, digamos, que não tem a ver simplesmente com os objetos, no sentido tradicional do empirismo, mas com os matters of concern, com as coisas que constituem causas, em oposição aos objetos ${ }^{1}$. Eu gosto dos antropólogos, gosto dos sociólogos (um pouco menos, talvez!), gosto dos filósofos (um pouco menos ainda!), e gosto muito dos science studies, este é o meu domínio, que, em parte, eu mesmo criei, juntamente com amigos, e o domínio de pertença é sempre importante. É nele que encontro os colegas mais queridos.

Você utiliza a antropologia clássica para criar instrumentos metodológicos que permitam uma nova abordagem da ciência moderna. Isso implica, segundo você, a constituição de uma antropologia simétrica. Em que sentido a empresa de uma antropologia da modernidade pode contribuir para renovar a antropologia geral?

Comecei pela utilização bastante clássica da antropologia definida como etnografia, como método etnográfico. Se pensarmos na formação clássica em antropologia tal como se fazia há mais ou menos trinta anos, veremos que não havia muitas formas de aplicá-la ao estudo das atividades científicas do centro. Em troca, o método etnográfico era utilizável. E assim alguns autores, como Mike Lynch, na Califórnia, Karin Knorr, também na Califórnia, Sharon 
Traweek (uma verdadeira antropóloga entre os sociólogos) e eu mesmo, sempre na Califórnia, por acaso e sem nos conhecermos, utilizamos os métodos etnográficos. E foi apenas depois que trouxemos o problema para a antropologia geral que nos defrontamos rapidamente - ou rapidamente para mim - com a questão "N atureza/Cultura", mononaturalismo e multiculturalismo.

Nessa época, na Califórnia, você já possuía alguma formação em antropologia?

Sim, porque eu já havia passado dois anos na África pela ORSTOM2, onde tinha bons colegas, como Marc Augé.

Você fez o serviço militar na África, não é?

Sim. Fiz o meu primeiro trabalho de campo lá, sobre a formação de trabaIhadores de médio escalão em fábricas na Costa do Marfim. Eu já era, então, um sujeito híbrido, uma vez que estava na Costa do Marfim, mas estudava um assunto relativo à modernidade. Aplicávamos o método etnográfico, mas não abordávamos as grandes questões da antropologia. Estas encontramos depois, quando começamos a fazer estudos de campo, e aí nos demos conta de que os antropólogos não compreendiam nada do que fazíamos, pois eram obcecados pela distinção "Natureza/Cultura", uma natureza e várias culturas. Foi nesse momento que conheci Philippe Descola e Marshall Sahlins e, em seguida, Eduardo Viveiros de Castro. Com eles, as minhas discussões começaram a se aproximar realmente da antropologia. Foi então que publiquei Nous n'avons jamais été modernes (1991), que foi um momento-chave para mim, quando entrei em contato com os antropólogos, que começavam a dizer haver ali algo de interessante para eles, pois, até então, não se haviam aplicado métodos etnográficos à distinção “Natureza-Cultura". Penso que, desse ponto de vista, prestei um serviço aos antropólogos. Mas será que isso abalou a antropologia como um todo? Não. Porque, de início, nada abala a antropologia e as disciplinas acadêmicas em geral, e também porque as ciências continuam a interessar apenas a pouquíssimas pessoas. Assim, afora Descola e Viveiros de Castro, um pouco Sahlins, o impacto da antropologia das ciências como a que faço sobre a antropologia geral é, creio, nulo. Por outro lado, há pessoas como Paul Rabinow, toda uma série de antropólogos pós-modernos, que mantêm laços mais fecundos entre os science studies e a antropologia. Mas isso permanece sempre meio marginal na antropologia, como vocês sabem muito bem, pois são antropólogos.

Por que a influência dos science studies se fez sentir mais nos Estados Unidos, e tão pouco na França?

Na França, isso não teve absolutamente qualquer influência, salvo no curso de Descola, ou na Inglaterra, um pouco por M arilyn Strathern, que estabeleceu conexões muito produtivas entre os science studies e a antropologia. Na Alemanha, tenho a impressão de que não houve grande influência. Assim, a antropologia continua o debate entre ciência e cultura3. Sobretudo, isso não teve qualquer influência no lugar onde justamente teria de ter tido, ou seja, nas relações entre a antropologia física e a antropologia cultural. Era lá que estava - e ainda está - o futuro, o impacto futuro dos recursos intelectuais mobilizados pelos science studies. E esse traba- 
Iho ainda nem sequer começou, apesar de ser interessantíssimo. As coisas não caminham rápido na vida intelectual.

Qual é, para você, a diferença mais significativa entre a (nova) antropologia das ciências e a assim chamada filosofia das ciências?

Aqui, o contraste é total, entre a epistemologia (ou filosofia da ciência) e os science studies. Há ainda um terceiro personagem, que é a história das ciências, hoje em dia muito desenvolvido na França e muito interessante. Há muitas coisas agora. Assim, há Ian Hacking, que é, aliás, um colega de Descola no Collège de France, um caso típico dessa hibridização entre filosofia, história e sociologia das ciências. M as ele não é francês, é canadense... Durante muito tempo, a única maneira de se pensar a ciência na França era a epistemologia. Mas isso mudou muito, pois há Hacking no Collège de France; há, ao redor de Dominique Pestre, historiadores da ciência numerosos e de ótima qualidade, de nível internacional. Assim, a situação agora é bem mais rica. Há muitos bons trabalhos do que podemos chamar de science studies na França, sobre a França, e feitos por franceses. A ligação com a antropologia, creio, permanece débil, pois seria preciso que os antropólogos se interessassem, justamente, pelo centro. Há poucos antropólogos que fazem isso, e quando o fazem, é da maneira mais superficial possível.

Poderíamos dizer que esses antropólogos que trabalham com o tema da modernidade não se interessam senão pela "periferia" da cultura ocidental?

Sim, é isso, a periferia do centro! E não o centro do centro! Ou tampouco a pe- riferia, aliás. Agora não sabemos muito bem onde é o centro e onde é a periferia. Os antropólogos não se interessam pelas multinacionais, eles não se interessam pela indústria, pelas técnicas. Mas não posso Ihes falar sobre a antropologia na França. Sobre esse assunto, seria melhor vocês entrevistarem Descola, pois eu não freqüento os antropólogos - só freqüento os melhores! Eu não freqüento todos os outros; não estou habilitado a responder a essa questão. Mas o ponto é que, de fato, meu projeto vem mudar a antropologia em geral. Se deslocarmos o debate de conceitos como "mononaturalismo" e "multiculturalismo" para novos conceitos, faremos a antropologia mudar. Quando Viveiros de Castro inventa sua história de "multinaturalismo", ele chuta o pau da barraca. Isso é certo. Assim, depois disso, a antropologia deve se refazer. Mas quais são aqueles que têm consciência desse problema, além das três pessoas já mencionadas?

Você apresenta o projeto, a Constituição M oderna, como algo fadado ao fracasso. Quais são os signos deste destino trágico, uma vez que a ciência parece continuar ocupando um lugar de centralidade na produção de nossas verdades? Se é assim, por que não podemos mais ser modernos? Nós jamais fomos modernos, ou fomos, uma vez, mas agora deixamos de sê-lo? Retrospectivamente, de acordo com sua teoria, nós já não éramos, antes, modernos. $M$ as éramos mais modernos que hoje? Somos menos modernos que há trinta anos?

Sim, isso é certo. Não tenho provas, pois todos os signos podem ser reinterpretados dentro de uma lógica de desenvolvimento modernista. Eu não possuo uma só prova - o que me preo- 
cupa muito, aliás - de que a história e a flecha do tempo modernistas não sejam verdadeiras. Se formos habermasianos, a lógica do desenvolvimento dos últimos cinqüenta anos pode ser perfeitamente compreendida como o avanço da modernidade, da "hipermodernidade", como disseram alguns, com o pequeno problema da pós-modernidade, entretanto, que é um sintoma bastante forte. Então, o que eu faço é simplesmente oferecer uma outra interpretação, dizendo: se olharmos as coisas de um modo diferente, é possível que o que está acabando seja uma modernidade que jamais existiu de fato: jamais fomos modernos. É paradoxal. Mas, ali onde eu possuo as provas que os outros não possuem, é porque, digamos, mais uma vez, graças à história da ciência, graças aos science studies, nós nos demos conta, finalmente, de que o único disparador e as únicas provas de que os modernistas dispõem para fazer o seu quadro de desenvolvimento do Homem modernista - da Renascença até hoje - são as ciências. É Galileu, é Newton, Pasteur, Einstein etc. Ora, é justamente isso que, juntamente com os historiadores da ciência, meus amigos, pudemos revisar de algum modo. Porque agora temos a história de Galileu, a história de Newton, a história de Pasteur, a história de Einstein. A cada vez, em lugar de encontrar uma separação entre objetividade e subjetividade, encontramos o contrário. Foi isso que contei na minha pequena conferência no Collège de France, no quadro do seminário de Descola. Para nós, que somos historiadores da ciência, no sentido dos science studies, as provas de que jamais fomos modernos são mais fortes, pois dispomos justamente dos exemplos das ciências, que nós revisamos. Por isso a idéia de uma Grande Narrativa modernista parece hoje em dia bem menos crível. Mas não é propriamente um destino trágico não ser moderno. $\mathrm{O}$ que seria trágico seria o fato de sermos mesmo modernos. Este sim seria um destino trágico. Aliás, os modernistas já choraram todas as lágrimas disponíveis para explicar que ser moderno era terrível, era desencantar-se etc. Então o fato de jamais termos sido modernos não é absolutamente uma tragédia. É justamente o contrário! Os europeus jamais abandonaram a matriz antropológica ordinária4. Agora temos a prova disso, pois Descola está mostrando que o modernismo é um dos quatro casos de identificação com a natureza: o naturalismo, ao lado do analogismo, do totemismo e do animismo. É um caso digno de interesse, mas é uma variante entre outras. Não é mais o horizonte para o qual evolui o resto do mundo. Isso coloca evidentemente problemas políticos enormes, que Descola não resolve. Descola tem muitas qualidades, mas sua política é completamente clássica.

Mas há algo realmente inédito, historicamente falando, no que dizem e fazem os modernos...

Sim, eles são originais. O naturalismo é muito original. Eles são interessantes. O modernismo é uma particularidade antropológica interessante. Certamente - não o nego. E podemos mesmo ir mais longe. Essa particularidade explica muito de seu dinamismo. É porque estivemos constantemente a imaginar a purificação que pudemos operar a hibridização. Essa hipótese, que formulei sem a menor prova em 1991 em J amais fomos modernos, eu diria que se acha hoje, no fim das contas, razoavelmente confirmada. Aliás, devo agradecer por isso, em parte, aos trabalhos dos antropólogos. É graças ao fato de o modernismo não ser uma realidade, mas uma 
interpretação da realidade que tem um efeito muito importante sobre esta, que podemos agora fazer uma antropologia do dinamismo dos modernos. É precisamente porque eles estão constantemente a trabalhar com a idéia de purificação que puderam produzir esses hibridismos, que os outros - diríamos hoje, os analogistas ou os multinaturalistas - se proíbem. Eu falei disso algumas vezes com Sahlins e com Viveiros de Castro, e creio que essa não é uma hipótese absurda, ainda que continue sem poder prová-la. O dinamismo dos modernos é ter feito constantemente outra coisa que aquela que pretendiam fazer. A comparação com a China é muito interessante, com os chineses conforme imaginados e reconstruídos por François J ullien 5 , pois lá vemos muito bem a diferença de um pensamento que procura, ao contrário, ficar o mais próximo possível da prática. É muito interessante, mas nós, do lado ocidental, não compreendemos esse pensamento, pois ele nos parece banal. Ora, essa banalidade é, segundo J ullien, justamente a força e o interesse desse pensamento, que se recusa a dramatizar suas preocupações.

Então, eu não possuo signos, possuo índices que reinterpreto sob outra ótica. Mas se vocês me perguntam qual é a prova que eu tenho de jamais termos sido modernos... bem, eu não tenho provas! Todos os meus amigos pensam que minha hipótese não é verdadeira, que a modernização avança; mesmo aqui [no CSI] — vocês podem perguntar a meus colegas - ninguém acredita na minha hipótese. Todos pensam que a modernização continua; muitos crêem que nós nos tornamos pós-modernos. É de se espantar, pois esse livro que eu escrevi em três semanas foi publicado em dezoito línguas! É uma hipótese que interessou a muita gente, mas que eu não consigo de maneira nenhuma provar.

Para voltar a Philippe Descola, ele fala de uma ontologia naturalista. Você fala de uma constituição moderna que oculta ou encobre, digamos, um lado não-moderno e que poderia ser chamado, para continuar com os termos de Descola, de animismo, totemismo ou analogismo. Que acontece, então, em sua própria reflexão, com essa noção de ontologia?

Essa é uma questão difícil... Não sei. Os naturalistas são realmente naturalistas? Sim e não. $\mathrm{Na}$ perspectiva de Descola, o naturalismo define um certo modo de identificação. Ora, penso que isso não é certo no que diz respeito aos modernos, pois define apenas o lado de sua empresa que corresponde à representação oficial que eles têm de si mesmos, e da qual têm necessidade para construir os recintos [enceintes] dos matters of fact. Mas ao mesmo tempo, no interior desse recinto, que é, grosso modo, seu laboratório, eles vivem de uma maneira bastante diferente. Por exemplo, os átomos que, em uma ontologia naturalista, são supostamente tão exteriores a nós, exibirão, no laboratório, um monte de outras ontologias - no plural - , uma porção de estados ontológicos que contradizem flagrantemente a visão pedagógica e epistemológica oficial. Essa contradição não é entre o velado e o revelado, mas entre o recinto e o que ele permite. Não é a mesma coisa. É porque os modernos estão protegidos das conseqüências de sua hibridização que eles se permitem tais coisas.

A questão diz respeito ao recinto. É exatamente como se nós tivéssemos uma central nuclear e, para fazer essa central nuclear, fosse necessário cons- 
truir recintos sólidos para proteger o que se passa no núcleo do reator, separando-o muito bem do exterior. Que é, então, necessário estudar? Os recintos? O núcleo do reator? O exterior? Tudo, provavelmente. Se nos interessarmos pelo recinto, diremos que os modernos possuem uma ontologia naturalista é isso o que diz Descola - , mas se nos interessarmos pelo que se faz dentro dos recintos, veremos algo muito diferente. Isso não quer dizer que eles sejam animistas - os modernos não podem ser de modo algum animistas, totemistas ou analogistas. Bem, analogistas talvez seja mais provável, pois herdamos muito do analogismo... Vêse isso muito bem, aliás, no belo livro de Foucault, As palavras e as coisas. Herdamos muitos aspectos do analogismo. O problema é que não sabemos como se passou do analogismo ao naturalismo, da "prosa do mundo", como diz Foucault, à Natureza modernista. O fato é que há pouca antropologia do modernismo. Temos muito menos estudos, curiosamente, sobre as nossas ontologias que sobre a ontologia dos Achuar, por exemplo. Então não temos respostas a essas questões. Pessoas como Descola e Viveiros de Castro costumam dizer: "estudo os outros e não nós, e por isso não considero os naturalistas modernos por aquilo que eles fazem realmente, mas apenas por aquilo que eles dizem oficialmente sobre si mesmos". E assim, o paradoxo é que sabemos menos sobre as ontologias mobilizadas pelos biólogos, pelos técnicos de computação, pelos empresários, que sobre aquelas mobilizadas pelas práticas de caça achuar. Porque pensamos que os brancos, os habitantes do centro, realmente possuem uma ontologia naturalista. Isso é uma verdade tão superficial que acaba por se tornar completamente falsa. (Os brasi- leiros são interessantes porque eles jamais acreditaram, no final das contas, nessa história de purificação. Eles possuem uma visão que difere daquela do modernismo dos franceses.)

Então, direi, para retomar os termos da questão de vocês, que não se trata aqui de uma ontologia pura e simples, mas de uma ontologia que ainda não conhecemos, em virtude da falta de estudos. Mas quando estamos diante de alguns bons trabalhos - como, por exemplo, o belíssimo livro de Hans J org Rheinberger sobre os seres biológicos em um laboratório contemporâneo - , vemos que a ontologia naturalista de Descola e Viveiros de Castro não parece descrever muito bem o que se passa nesse laboratório. Coisas estranhas acontecem com os seres biológicos. Isso não quer dizer que os biólogos sejam animistas, isso significa que acontecem coisas que a criação do recinto modernista permite. Quando se está no recinto modernista, é possível fazer experiências sobre as ontologias que não se pode fazer quando se está no terreno do animismo. É essa a diferença crucial, é essa a particularidade do naturalismo. Mas aqui há uma questão técnica que tomaria muito o nosso tempo.

Tomemos a questão anterior sob um prisma diferente. Os modernos detêm uma certa constituição, que Ihes permite encobrir o que se passa realmente dentro de seus recintos. Entre os prémodernos, ao contrário, poderíamos dizer que tudo se passa de uma maneira diferente, que eles são mais transparentes e que jamais se enganam. Ou seja: o que eles dizem, eles fazem. $O$ "engano" seria um atributo dos modernos. Podemos dizer que os modernos encerram uma contradição mais séria que os demais? Se isso é verdade, eles 
se tornariam realmente diferentes dos outros, situando-se em uma posição realmente assimétrica.

É muito interessante essa questão. Eu e Viveiros de Castro já discutimos muito sobre esse ponto. Não é absurdo dizer que a particularidade dos modernos é estar em maior contradição consigo mesmos que os demais coletivos. O caso dos chineses é, nesse sentido, extraordinário; tomemos mais uma vez os chineses de Jullien, que descreve efetivamente as suas práticas. $M$ as na nossa perspectiva, a dos modernos, criadores de recintos no interior dos quais se faz algo diferente, o objetivo da sua filosofia [dos chineses] não é descrever as suas práticas, mas criar condições para que isso que eles sabem na prática possa ser levado às últimas conseqüências, com energias consideráveis, pois os pressupostos e conseqüências das conexões são mantidos em desconhecimento. Costumase concluir do fato de "jamais termos sido modernos" o fato de que os modernos teriam se enganado. Não é essa a questão - sou geralmente mal compreendido nesse ponto. $M$ ais uma vez: quando se está numa central nuclear, nunca se está dentro, mas fora; ninguém vai querer entrar, pois dentro tudo irradia, tudo queima, e é porque se está fora e que há um recinto de contenção que se pode, no interior, fazer coisas com energias formidáveis, incomensuráveis, com o que se passa no exterior... É preciso levar em conta as energias das experiências modernas. $\mathrm{Se}$, a cada vez que começamos a estabelecer os protocolos dessas experiências nós nos dissermos: "isso tem influência sobre a sociedade, sobre o cosmos, sobre os ancestrais, sobre os cultos" etc. se, a todo momento, não tirarmos os olhos do fato social total da nossa própria cultura, seremos obrigados a tomar graves precauções, teremos de tomar muito cuidado. E com isso, viveríamos em uma atmosfera de desaceleração.

A questão de vocês é muito astuciosa. Não se trata de dizer: "todos os outros fazem o que dizem, e nós, modernos, temos a particularidade de mentir, nós mentimos!". Superficialmente, isso é verdade. Mas é preciso fazer as duas coisas ao mesmo tempo, senão não poderemos nos permitir liberar energias. Essa é a grande astúcia dos modernos: ter uma constituição que possui dois ramos. O primeiro permite alegar: "quando você faz isso, você pode misturar o que bem quiser, e as conseqüências não vão existir". O segundo, por sua vez, constata justamente que essas conseqüências existem. “Ah, sim, destruímos a floresta amazônica, transformamos completamente as grandes planícies norte-americanas. Uau, isso é estranho, como isso pôde acontecer?" Não se pode negar que haja para os modernos um contraste excessivo entre o que eles dizem e o que fazem. É isso que explica sua surpresa total diante das conseqüências inesperadas de suas ações. Eles dizem que são emancipados, mas ao mesmo tempo: "ah, é estranho... hoje estamos novamente reconectados à atmosfera, ao ar que respiramos. Como isso aconteceu? Isso aconteceu porque tivemos uma influência tão grande que acabou alterando o próprio clima". Nós dizemos, finalmente: "Olhem só, estamos realmente reconectados!". Pois é, estamos reconectados. Os outros sabiam. Isso não causa espanto aos outros. E aqui há uma verdadeira diferença. Os outros nos dizem: "Welcome back!". Nós lhes perguntamos: "Vocês não são emancipados?". E eles respondem: “Não! Nós sabíamos. Nós, os outros, sabíamos um 
pouquinho das coisas". A húbris moderna, que foi estudada por todos os modernistas - esse é o grande tema da crítica. Há qualquer coisa de verdadeiro nesse tema da húbris. De qualquer modo, se todas as questões de vocês forem tão difíceis como esta, eu não poderei mais responder...

Então, se a constituição moderna é oficial, mas não oficiosa, podemos voltar a falar em uma ontologia de base - e por que não dizer universal? - ligada às práticas de "tradução" ou "hibridização", essas que tornam impossíveis todos os esforços de purificação? Você defende a idéia de que todos os coletivos são híbridos. É isso que tornaria possível a simetrização e a comparação entre os modernos e os outros?

A questão do universal não me parece apropriada. Não é um modo ideal para se falar do mundo. O problema é: será que podemos viver no mesmo planeta, sabendo que temos definições completamente diferentes sobre o planeta, sobre o que é viver e o que é estar junto? $E$, nesse ponto, a comparação deixa de ser intelectual, para ser uma comparação que podemos chamar, com Isabelle Stengers, de cosmopolítica, mas não no sentido de Ulrich Beck ou de Kant. Talvez fosse necessário falar, como Peter Sloterdijk, em domo ou envelope. Qual o domo no interior do qual se faz a comparação? Esta é, em si, uma questão importantíssima. A solução clássica dos antropólogos é dizer que nós sabemos o que é esse domo, ele é o conhecimento, a natureza, a natureza humana, essa mansão da modernização para onde se encaminham as culturas, sob uma forma geralmente triste - "tristes trópicos", eis a fórmula que resume todo um passado. Elas entram na mansão, nós as honramos, elas se modernizam e se dissolvem em todos sentidos. O imaginário da antropologia é uma estátua cuja encarnação foi Lévi-Strauss.

Ora, a situação atual é completamente diferente, pois não há mais o domo da natureza, e menos ainda o tema do desaparecimento das culturas, pois há a formação de novas culturas completamente bizarras, híbridas, à maneira de Appadurai, feitas de mercado mundial, de marketing, de arcaísmo, de folclore etc. $E$ a assembléia que permitiria essa conexão não existe. Por isso, a situação se torna realmente interessante, pois agora a comparação deixa de ser "somos todos de diferentes culturas, sobre o pano de fundo de uma mesma natureza", para ser "o que nos espera?". E assim essas questões vão ficando cada vez mais interessantes. É isso que eu queria dizer sobre o tema da nova forma de auto-apresentação dos europeus. Os europeus se representam e se apresentam novamente aos outros, de modo agora polido, dizendo: "não sabemos em que mundo estamos". Tomemos a famosa disputa de Valladolid. Valladolid versava sobre os índios. E, como lembram LéviStrauss e Viveiros de Castro, será que os brancos estavam de acordo com eles? Antes, a questão era simples, era a do universal local, tal a controvérsia de Valladolid. Mas... e se dissermos: “qual é a diplomacia necessária para que haja um mundo comum entre esses que dizem 'Em Valladolid, experimentam-se almas; em Porto Rico, experimentam-se corpos'"? Não há mais mundo comum a abrigar estes dois extremos. De fato, e estamos mesmo assim engajados ora em uns, ora em outros, obrigados a estar em guerra para poder fazer a paz. E assim as coisas vão ficando interessantes. 
Retomemos, antes de prosseguir, a sua noção de "hibridização" ...

Hibridização não é um bom termo. Se o empreguei, foi simplesmente para testá-lo. "Híbrido" é já todo um mundo da genética. Usei o termo "híbrido" para começar a discussão, ele descreve bem o fato de que quando você fala em garrafas de água mineral, por exemplo, você vai encontrar a legislação, os problemas de poluição e a água vai se pôr a diferir, a se complicar, deixando de estar situada como um matter of fact. Só que hoje eu não utilizaria mais o termo híbrido, pois, a rigor, só há híbridos, em toda parte. Se assim fosse não poderíamos mais fazer a distinção entre animismo, totemismo etc.. Mas nós produzimos um tipo de híbrido que é muito interessante: o ato da hibridização é negado em seus recintos. Se o recinto exibe matters of fact, seu interior é codificado. Essa é a nossa invenção. É uma coisa engraçada. E nós, não nós antropólogos, mas nós que fazemos a cosmopolítica, nós dizemos que a tarefa da política é abrir o recinto e mostrar o que ele é e o que permite, ou seja, os matters of concern. Essa oposição está um pouco em toda parte: sobre a guerra no Iraque, por exemplo, diremos: "esta vai ser rápida, vai dar tudo certo, nós controlamos tudo". Mas tudo dá errado, como vamos sair dessa, estamos enrascados... Nós vivemos neste momento uma oposição particularmente dramática. Temos as provas absolutas de que há armas de destruição em massa, e então, de repente, damo-nos conta de que não as temos, estávamos enganados. Essa oposição está por toda parte. Fatos indiscutíveis são substituídos por fatos discutíveis.

Como definir essa noção de cosmopolítica?
Há muitas definições, mas eu prefiro aquela de Isabelle Stengers. Ou seja, a de que a "política" são os humanos, e que o "cosmos" são as coisas: nenhum dos dois sozinho é o bastante. A palavra "cosmopolítica" é uma palavra que permite dizer que se fizermos a política apenas entre humanos, vamos acabar nos fechando em uma esfera exígua demais, feita de interesses de boa vontade. Se tivermos apenas cosmos, iremos nos encerrar sozinhos na velha idéia dos naturalistas, que definem a priori um mundo comum que os outros devem compartilhar. A cosmopolítica permite impedir que os dois se fechem: o cosmos está lá para impedir que a política se feche, e a política, para impedir que o cosmos se feche. $O$ cosmos não é mononaturalizado, ele é a expressão de uma política. Acredito que podemos dizer hoje que temos uma prova para esse fenômeno, e esta é muito difícil de ser negada. O número de fatos, que aparece ainda sob a forma modernista de matters of fact, diminuiu muito em relação aos fatos que aparecem agora sob a forma de matters of concern. Nós não podemos ainda quantificar a mudança, mas há uma grande mudança. Podemos também interpretar isso alegando que, não, é simplesmente o modernismo que tenta avançar, mas esse tipo de interpretação acaba parecendo com os epiciclos ptolomaicos. Enfim, não se deve acrescentar epiciclos a epiciclos. Não é um modo honesto de pensar.

Tomemos, como exemplo, o caso das descobertas sobre o genoma humano. Fala-se muito, nos termos de Viveiros de Castro, em "multinaturalismo", ou seja, múltiplas naturezas. Ora, as descobertas recentes sobre a biotecnologia genômica insistem sobre uma base biológica certamente universal, que 
nos reenvia forçosamente ao mononaturalismo. O que é encoberto nesse processo? Ou, dito de outro modo: não teria a antiga constituição moderna encontrado, ali, a sua realização?

Este é o gênero importante de questão, pois estamos aqui no cruzamento entre antropologia física e antropologia cultural, social. Esse cruzamento deverá ser, no futuro, o cerne da antropologia. $M$ as reflexões como essas não foram praticamente realizadas. Mas há um modo típico de responder à questão de vocês. Podemos, e há gente que o faz, saudar a genômica como o grande evento dos últimos vinte anos. Podemos efetivamente repetir a narrativa do modernismo com a biologia no centro. Ao mesmo tempo, entretanto, verifica-se uma proliferação de definições do gene, das influências dos genes, que reduziu a nada a universalidade do discurso biológico. Este é tipicamente um problema modernista. Todo mundo tem o mesmo genoma, estamos todos finalmente unificados sob o teto da mansão da genética. Sim, mas, simultaneamente, as definições do gene, das influências do gene que serviam para unificar essa mansão, explodiram em uma multiplicidade de definições. Por exemplo, muita gente tem síndrome de mongolismo, mas não manifesta o mongolismo. Pierre Sonigo, que é um grande biólogo francês e que escreveu, no ano passado, um livro apaixonante sobre o gene, oferece uma definição completamente oposta6. Ele diz não, o gene não é algo que transporta as informações, mas algo que come. Já não é a mesma coisa. Todas as conseqüências que você pode tirar de um e de outro para a unificação do comportamento são diferentes. Evelyn Fox Keller publicou, no ano passado, The century of the gene, onde argumenta que o dis- curso sobre a ação do gene é uma pequena fração, agora, do que se passa na genética7. Há aqui gente que estuda as questões relativas às doenças que são devidas a um gene apenas, e mesmo assim observamos diferenças enormes. Sem falar do fato de que agora um gene é uma empresa, são patentes, é um jogo geopolítico enorme como vemos com o caso dos transgênicos. É por isso que a relação entre a antropologia física e a antropologia cultural tornou-se tão interessante de um ponto de vista político. Estamos diante de um lugar de controvérsias, pois podemos dizer: “Olha, temos razão de fazer antropologia física, pois agora isso já está unificado". E, ao mesmo tempo: "Olha, temos uma rica antropologia social - digamos assim - dos genes, porque a genética é assunto das mais variadas controvérsias". Isso é normal, pois não há uma única maneira de um corpo existir no mundo. Os geneticistas não sabem o que fazem. É que o problema do gene é complicado. Um gene é múltiplo e os seus modos de ação são múltiplos. Não há um só discurso sobre o gene que possa unificar a genética.

A questão de vocês é muito interessante e a minha resposta a essa questão é: eis porque é preciso uma antropologia da ciência. É preciso conseguir compreender as duas coisas: o discurso unificador triunfalista dos geneticistas - quando estes dizem que "o genoma é, finalmente, o fim da diferença cultural, porque temos agora um só gene para tudo", e o seu contrário, ou seja, a idéia de que o gene não explica tudo: fazemos genômica, agora temos o Genoma, e nos damos conta de que não é isso que explica tudo, é preciso olhar para as proteínas etc. O objetivo da antropologia não é opor o discurso oficial ao discurso oficioso, mas estudar os 
dois. E explicar por que o primeiro permite uma parte do segundo ao mesmo tempo em que impede o seu desenvolvimento. Hoje o desenvolvimento da genética está paralisado por um discurso que não corresponde, de modo algum, àquilo que o ser deve fazer, presa como está à estranha ontologia do antigo gene codificante e informante, algo como a imitação de um livro, algo que se assemelha à linguagem.

Você fala da crise da representação política como parte da crise da modernidade. Em que sentido você pode dizer que a democracia - ao mesmo tempo o melhor e o pior sistema político, para retomar a frase de Churchill que você mencionou em uma conferência recente - deve ser estendida às coisas?

A política sempre foi, de fato, uma política das coisas. A questão foi sempre construir cidades, definir fronteiras e paisagens. Foi a filosofia política que inventou, em meados do século XVII, uma teoria da representação unicamente do mundo social humano, ao colocar a economia e as ciências do outro lado. Isso significa que, do ponto de vista da atividade que chamamos política, sempre se tratou de questões - issues, como dizem os ingleses - , que são preocupações não simplesmente materiais, mas preocupações em relação a bens e coisas. A melhor demonstração disso é um afresco muito conhecido de Lorenzetti, em Siena, Do bom e do mau governo. A diferença entre o bom e o mau governo é que no mau governo há coisas que são destruídas, ao passo que no bom governo as coisas são coerentes. Não fui eu quem inventou a política das coisas (a democracia das coisas, sim). É a filosofia política que a esqueceu e que durante alguns séculos definiu a política como um pro- blema de representação dos humanos, de tomadas de posição dos humanos, mas não como uma cosmopolítica. Agora que jamais fomos modernos, com o problema que expliquei há pouco, começa a ficar claro por que o senhor Lula tem de se ocupar do aquecimento do globo, do milho híbrido, da pobreza, da habitação, da crise do abastecimento de água etc. É evidente por quê.

Podemos dizer que o problema da ecologia esteve sempre no centro da política?

Sempre esteve no centro da política, mas nem sempre no centro da filosofia política. Agora o problema é que a filosofia política deve absorver de novo as coisas que estavam antes nas mãos exclusivas dos experts científicos - os genes de que acabamos de falar são um ótimo exemplo disso - , e que agora migram para o centro da atenção comum. E aí, a democracia das coisas é uma outra história. É o "parlamento das coisas". Este é o problema da exposição Making Things Public ["Tornar as coisas públicas"], que estou preparando em Karlsruhe, na Alemanha. Retomando, portanto, a questão de vocês: não se trata apenas da representação dos centros da vida política em torno da eleição e da autoridade, mas a representação também no sentido bem conhecido "dos instrumentos que representam as coisas de que falamos". Assim, a questão da democracia atual não é apenas saber se nós votamos ou não, se estamos ou não autorizados pelas pessoas que nos elegeram, o que é a primeira parte da representação, mas também a de saber como, quando falamos do milho transgênico, essa coisa de que falamos é representada, desta vez no interior do recinto. Por isso, a "democracia das coisas" quer dizer, 
justamente, o duplo interesse pelos dois sistemas de representação: representação dos humanos que falam das coisas, e representação das coisas de que os humanos falam, em seus recintos. Um caso típico de mau exemplo de representação é o do Mr. Collin Powell quando diz à ONU: "Olha, eu tenho a prova de que há armas de destruição em massa, e posso exibi-las na tela". E ele nos mostra péssimas imagens falsificadas etc. Há uma carência de representação. Não estou dizendo que Bush não é autorizado, ele foi eleito. Mas o que ele faz não é representativo. A democracia das coisas é transportar de um modo confiável as coisas de que falamos e, por outro lado, estar autorizado para falar delas por meio de um procedimento social. Trata-se de uma questão extremamente simples, mas que a filosofia política não abordou, pois ela fez uma separação completa entre, de um lado, as coisas que são representadas pelos cientistas, mas fora do procedimento político, e a representação dos humanos. $M$ as no meio disso tudo havia a retórica, que era justamente uma forma de comunicação e manipulação, uma espécie de relações públicas, e não o trabalho público sobre as provas incompletas. A retórica jamais foi - a não ser entre os gregos, certamente - pensada como sendo o meio essencial de reconduzir as coisas aos recintos ocupados por aqueles que falam delas. Assim, essa questão toca de fato no problema da invenção de uma retórica política.

\section{É porque a retórica é uma técnica...}

Sim, mas que foi muito importante durante vinte e quatro séculos e que desapareceu completamente no fim do século XIX. Desapareceu, pois a ciência não poderia ser, supostamente, uma retórica. Mas é claro que é necessário que ela seja uma. É necessário ser capaz de dramatizar, verificar, encontrar, expressar, convencer, ser compreensível por um grande número de pessoas. $\mathrm{E}$ isso corresponde exatamente às armas e às grandezas da retórica clássica.

Parece que o que nos falta, hoje em dia, não é a retórica em si mesma, mas justamente uma espécie de “rigor retórico"...

Podemos falar de rigor retórico, vocês têm razão. Infelizmente, opomos retórica e rigor. É bela essa expressão de vocês... Vejam só, por exemplo, Collin Powell em um episódio muito interessante em que ele foi obrigado a dizer: "These are not obsessions, my friends, these are facts". Ele foi obrigado a dizer isso perante o Conselho de Segurança da ONU. Evidentemente, não se tratava de fatos indiscutíveis. Ele bem sabia. Se ele tivesse seguido o rigor retórico, ele talvez pudesse ter dito: “Eu não sei o que se passa de fato, eu possuo provas muito pouco claras. M as elas são importantes demais para que deixemos de agir imediatamente". Aqui sim teríamos uma retórica rigorosa. Ele poderia, talvez, nesse caso, ter convencido alguém, mas a oposição entre fatos e retórica ("These are not obsessions, my friends, these are facts") torna impossível o rigor retórico. O que eu quero fazer nessa exposição é justamente dizer que há um duplo fenômeno de representação: representação do lado das coisas, e representação do lado das pessoas, e que é precisamente isso o que chamo de democracia.

Você disse, no seminário de Philippe Descola, em novembro de 2003, que é preciso que o Ocidente mude o seu contraste com os outros para que ele 
possa, enfim, fazer uma oferta de paz. Os antropólogos teriam, assim, um papel central nessa missão, e isso implica a definição da antropologia como diplomacia. Você poderia falar um pouco mais desse papel que o antropólogo deve assumir?

Já falamos um pouco disso. A diferença é que o diplomata não possui princípio superior comum, ele não conta com um árbitro indiscutível acima dele próprio para definir as posições e os papéis, porque senão não haveria guerra e não haveria conversações de paz, tampouco necessidade de diplomatas. A diplomacia é a busca dessas condições comuns em ambos os lados. Assim, esta é a grande diferença entre o antropólogo como diplomata e o antropólogo como erudito [savant]: o antropólogo savant reúne em seu escritório, no Collège de France, o conjunto de culturas que são convocadas, de certa maneira, sem dramas - senão o drama do conhecimento - e ele as compara umas com as outras reunindo-as num quadro, ao passo que o antropólogo diplomata não dispõe de um lugar particular para expor sua oferta de paz, ele pode ser considerado a qualquer momento como um traidor, pois não possui um princípio superior comum a partir do qual poderia arbitrar as diferentes posições. Ele não sabe o que é aceitável para as pessoas que o enviam, as pessoas de sua própria cultura, e tampouco o que é aceitável para os outros. Então há uma grande diferença entre o antropólogo savant e o antropólogo diplomata. M as este é um tema de debate com meus eminentes colegas.

Para além de um problema antropológico, a diplomacia seria também uma solução para o problema - ocidental, moderno - da globalização?
Os modernos serão simplesmente obrigados a pensar assim, porque eles não são mais os donos do mundo. Essa é a diferença. Antes, eles não precisavam ser diplomatas. Antes, como disse Sloterdijk, todo mundo achava formidável a globalização, quando nós éramos os únicos a globalizar. Do século XVII ao século XX, pensávamos que a globalização era ótima. Era o mundo, era a naturalização, era a modernização. Agora, todo o mundo globaliza. Os Kayapó globalizam, pois participam do mercado mundial com seus produtos... O problema é que os europeus agora são obrigados a serem polidos, pois eles não são mais os donos do mundo, e têm sorte de não mais o serem. Eles podem retomar as questões da antropologia clássica e concluir: “Agora não estamos mais na situação de antropólogos savants convocando o mundo todo simplesmente porque temos o poder indiscutível de fazê-lo em nome da Natureza"; pois entramos em uma tarefa diplomática arriscada, a de dizer aos outros, aos brasileiros, por exemplo: “Eis o que nós, franceses ou europeus, pensamos que devemos defender como nossa definição de existência, e se vocês nos tirarem isso, vocês brasileiros, nós morreremos". Isso é, portanto, muito interessante. Assim, o diplomata é uma figura que me interessa demais, pois acredito que ele seja uma figura maldita. $\mathrm{O}$ diplomata é o traidor. Ele é uma figura mais forte e mais antiga que a figura do savant. Havia diplomatas bem antes de haver savants. O diplomata é aquele que se engaja em questões sem saber ao certo em que coisas crer antes de iniciada a discussão. Assim, ele é obrigado a trabalhar de ambos os lados, tanto o daqueles para quem ele trabalha, como o daqueles a quem ele se endereça. Em uma antropologia diplomática, so- 
mos obrigados a nos engajar entre a química, os índios etc.

O diplomata chega no final de uma guerra que esgotou a todos. Assim, é preciso haver, antes de tudo, uma declaração de guerra: primeiro a guerra, depois o esgotamento; por fim, a diplomacia. O diplomata não aparece no começo, mas no fim. Se não há guerra e partes dispostas a negociar, não há diplomatas. Estamos em uma situação de guerra.

M as o que exatamente fazer no fim da guerra?

$\mathrm{Na}$ maior parte das frentes, a guerra ainda não começou. Não houve declaração de guerra. Este é um ponto muito importante, é o que eu chamo de "guerras pedagógicas". Na maior parte dos casos, não há ainda guerra, pois os modernos não faziam guerra, faziam pedagogia. Assim, quando eles dizem "saber racional" e "saber irracional", não se trata de guerra, mas de pedagogia. E aos irracionais dizem: “Não é sua culpa, não estamos em guerra contra vocês, nós gostamos muito de vocês, mas vocês são irracionais e nós somos racionais". Isso não é uma situação de guerra, e por quê? Porque supõe-se que haja um princípio superior comum que define essas duas posições, racional e irracional. Não está em discussão o que seja o "racional" e o "irracional". Ao passo que quando se diz: "para que haja guerra, é preciso haver declaração de guerra", e nada de árbitros, ou de princípio superior comum. É preciso dizer que a modernização desapareceu, que o mononaturalismo desapareceu, e assim por diante. Isso nos coloca muitas condições. Por isso, não apenas não estamos no fim da guerra, mas não chegamos sequer, em muitos casos, à declaração de guerra. Para a maior parte das pessoas, não estamos nem mesmo em guerra, estamos no desenvolvimento de técnicas que fazemos convergir para o mesmo mercado mundial. O diplomata é de fato a figura que chega depois que as pessoas já estão esgotadas pela guerra, que as conversações já começaram, e que as pessoas se perguntam: “no fundo, no que acreditar?". E então o diplomata refaz seu trabalho de redefinição de valores e diz: "Penso que nós acreditamos nisso. E agora eu me volto aos meus, e lhes digo: 'N ós acreditamos nisso. Você está de acordo que nós aceitemos isso para não retomar a guerra?'" E aí as pessoas podem dizer: "De modo algum. Esse diplomata é um traidor! Fomos vendidos pelo diplomata por um pedaço de pão." Eu fiz essa experiência. Fui aos cientistas europeus e Ihes disse: "Não se defende a racionalidade. $\mathrm{O}$ que se deve defender são os híbridos etc. Vocês estão de acordo?" Eles não estavam mesmo de acordo! De fato, podemos fracassar nas relações diplomáticas. Mas a diplomacia é algo muito interessante.

Nesse domínio, o que podemos pensar dos conflitos atuais entre os países ocidentais e os países islâmicos?

De qual guerra estamos falando? Trata-se de uma guerra dos modernos contra o arcaísmo? Não, evidentemente não. Trata-se de uma guerra entre dois modernismos, dois fundamentalismos. No mais, há uma série de assuntos sobre os quais os antropólogos não têm nada a dizer. Aqui eles deviam aprender com os islamólogos, e há alguns excelentes. $O$ que é certo é que não estamos diante de um conflito da modernização contra o religioso, mas de um modernismo extremo, que é um fundamentalismo, e que se assemelha 
muito ao nosso modernismo. Ficamos surpresos com essa constatação, pois o modernismo era ótimo quando éramos nós que o praticávamos, ou seja, quando era indiscutível, direto, quando não havia mediação. O fundamentalismo é algo muito interessante. Ele é um modernismo. M as nós, os modernos - nós jamais fomos modernos! -, nós sempre fizemos o contrário. Assim, quando vemos os verdadeiros modernistas diante de nós, ficamos horrorizados! Não porque eles tenham barba e vistam djellabas, mas porque esta é a imagem que nós mesmos demos ao mundo! Isso é extraordinário. É como um retorno. Sempre vimos a natureza e a ciência de modo indiscutível, construímos laboratórios etc. Mas vendemos o modernismo aos outros, aos praticantes. Este é o paradoxo. Agora, os outros dizem: “M as nós também somos modernos". "Ah bom! Mas então moderno significa o quê?" "Significa que as coisas são indiscutíveis, que não há mediação, não há história. E isso é ser modernista!" Recuo horrorizado dos europeus, que exclamam: “Não, não é isso, não pode ser isso!". O fundamentalismo é o modernismo amputado de seus híbridos, que agora se volta contra os modernos e os aterroriza - com razão. 


\section{Notas}

${ }^{1}$ No original, "des choses qui ont pris chose en opposition à l'objet". Latour usa o conceito de chose no duplo sentido arcaico de res ou ding, isto é, de coisacausa (causa jurídica ou política) "que remete [...] a um assunto levantado em uma assembléia, na qual se trava discussão que exige um julgamento passado em comum..." (Politiques de la nature, p. 351) [N.E.].

2 Office de Recherche Scientifique des Territoires d'Outre-M er, atual IRD Institut de Recherche pour le Développement [N.E.].

3 É possível que tenha havido aqui um lapso, e que Latour estivesse querendo dizer "Assim, a antropologia continua o debate entre natureza e cultura" [N.E.].

${ }^{4}$ Entenda-se, a matriz ou a condição humana, o modo de nossa espécie habitar o real - a "velha matriz antropológica", como a chama Latour em J amais fomos modernos [N.E.].

5 Sinólogo e filósofo francês contemporâneo, autor de importantes trabalhos sobre diversos aspectos e figuras do pensamento chinês. Ver o balanço de sua obra recentemente publicado em Penser d'un Dehors: la Chine (F. J ullien e T. M archaisse, Paris: Seuil, 2001) [N.E.].

6 Ver P. Sonigo e I. Stengers, L'Évolution. Paris: Edp Sciences, 2003 [N.E.].

7 Ver E. Fox Keller e L.L. Winship, The Century of the Gene. Cambridge, MT: Harvard University Press, 2002 [N.E.]. 